\title{
PENERAPAN METODE IMITASI DAN DRILL PADA PADUAN SUARA MANADO INDEPENDENT SCHOOL
}

\author{
${ }^{1}$ Ferdinand Tonies Paputungan, ${ }^{2}$ Alrik Lapian \\ ${ }^{1}$ Mahasiswa Pendidikan Musik Gereja IAKN Manado, ${ }^{2}$ Dosen Musik Gereja IAKN Manado \\ 1Paputunganferdinand@gmail.com, 2alriklapian@yahoo.com
}

\begin{abstract}
Abstrak
Paduan Suara Siswa Kelas VII di Manado Independent School merupakan kelompok paduan suara yang baru dibentuk dan sebagian besar anggotanya belum bisa bernyanyi dengan menggunakan teknik vokal yang baik dan benar disebabkan kurangnya pengetahuan mereka mengenai vokal dalam bernyanyi sehingga perlu menerapkan metode dalam mengatasi permasalahan tersebut. Tujuan penelitian ini untuk mengetahui penerapan metode imitasi dan drill pada Paduan Suara Manado Independent School. Penelitian ini menggunakan metode penelitian kualitatif yaitu studi kasus. Analisis diperoleh melalui lembar penilaian kriteria yang terdiri dari enam aspek pengukuran yang terdiri dari sikap tubuh, intonasi, pernapasan, artikulasi, phasering, dan ekspresi. Hasil penelitian memperlihatkan dua hal yaitu, pertama, bahwa penerapan metode imitasi dan drill meningkatkan teknik vokal yang baik, kedua, metode imitasi dan drill adalah metode yang tepat untuk diterapkan dalam pembelajaran Paduan Suara Siswa Kelas VII Manado Independent School.
\end{abstract}

Kata Kunci: Paduan Suara, Teknik Vokal, Metode Imitasi, Metode Drill

\section{APPLICATION OF IMITATION AND DRILL METHODS IN MANADO INDEPENDENT CHOIR} SCHOOL

\section{Abstract}

Choir Class VII Students at the Manado Independent School is a newly formed choir group and most of the members cannot sing using good and correct vocal techniques due to their lack of knowledge of vocals in singing so it is necessary to apply methods to overcome these problems. The purpose of this study was to determine the application of the imitation and drill method at the Manado Independent School Choir. This study uses qualitative research methods, namely case studies. The analysis was obtained through a criteria assessment sheet consisting of six aspects of measurement consisting of posture, intonation, breathing, articulation, phasering, and expression. The results of the study showed two things, first, that the application of the imitation and drill method improved good vocal techniques, secondly, the imitation and drill method was the right method to be applied in the learning choir of Class VII Students of Manado Independent School.

Keyword: Choir, Vocal Technique, Imitation Method, Drill Method

\section{Pendahuluan}

Pada jenis musik vokal, suara menjadi modal utama sehingga perlu untuk mempelajari teknik vokal agar dapat menghasilkan vokal yang baik dan benar.
Oleh karena itu dalam pembelajaran musik vokal perlu diperhatikan dan dipelajari mengenai penguasaan teknik vokal seperti sikap tubuh, pernafasan, intonasi, resonansi, artikulasi, bahkan ekspresi saat bernyanyi. Untuk menguasai 
vokal tersebut maka diperlukan metodemetode latihan dan pembelajaran yang tepat.

Metode-metode pembelajaran yang sering digunakan dalam mengajar diantaranya ceramah, diskusi, demonstrasi, tanya jawab, percobaan, resitasi, problem based learning, imitasi, drill (latihan), dan berbagai metode lainnya. Penggunaan metode-metode tersebut tentunya digunakan sesuai dengan materi pembelajaran yang diajarkan dan tidak semua metode pembelajaran tersebut sesuai dengan pembelajaran musik vokal karena khusus untuk pembelajaran vokal, pemilihan metode yang tepat akan mempengaruhi hasil dari pembelajaran vokal. Untuk itu metode yang digunakan haruslah metode yang dapat membuat siswa atau penyanyi paham mengenai vokal, serta mempraktekkannya dengan baik dan benar. Metode yang sering digunakan yaitu gabungan dari beberapa metode yang seperti ceramah, demonstrasi, solfegio, imitasi dan drill (latihan). Pemilihan metode juga mempertimbangkan kemampuan yang dimiliki oleh siswa yang akan diajarkan apakah siswa tersebut pemula atau tidak tentunya metode yang digunakan akan berbeda, karena untuk pemula metode yang tepat untuk digunakan adalah metode imitasi dan drill.

Metode imitasi tersebut yaitu tindakan atau cara guru memberikan gambaran atau contoh tentang bagaimana cara bernyanyi yang baik, kemudian siswa akan meniru apa yang diajarkan oleh guru tersebut, sedangkan metode drill yaitu kegiatan yang dilakukan dalam bentuk latihan berulang-ulang untuk mendapatkan keterampilan tertentu, tujuannya metode tersebut untuk melatih siswa, menghafal, memahami materi yang telah disampaikan oleh guru, oleh karena itu pembentukan vokal dengan metode imitasi dan drill tersebut diyakini dapat menghasilkan vokal yang baik dan benar. Metode seperti itu juga dibutuhkan dalam paduan suara, terlebih pada paduan suara pemula dimana suatu paduan suara dapat dikatakan paduan suara yang baik jika memiliki harmonisasi dalam suara. Pada pelatihan vokal paduan suara, metode tersebut bisa kurang maksimal jika pengajar hanya fokus pada penyelesaian suatu lagu untuk mengikuti even tertentu tetapi tidak mengajarkan vokal yang baik sesuai dengan teori yang ada, sehingga anggota paduan suara tidak memiliki pemahaman mengenai penggunaan vokal yang baik dan benar dalam bernyanyi paduan suara.

Paduan suara siswa kelas VII Manado Independent School merupakan kelompok paduan suara yang baru di bentuk. Berdasarkan observasi awal, sebagian besar anggota paduan suara belum bisa bernyanyi dengan menggunakan vokal yang baik dan benar. Hal ini disebabkan oleh kurangnya pengetahuan mereka mengenai vokal 
dalam bernyanyi. Dengan adanya permasalahan tersebut maka peneliti tertarik untuk melakukan penelitian mengenai penerapan metode imitasi dan drill pada paduan suara siswa kelas VII di Manado Independent School sehingga melalui metode tersebut, peneliti berharap kelompok paduan suara dapat bernyanyi dengan menggunakan vokal yang baik dan benar.

Berdasarkan latar belakang masalah, Peneliti memfokuskan penelitian pada penerapan metode imitasi dan drill di siswa kelas VII Manado Independent School.

Tujuan dalam penelitian ini untuk mengetahui penerapan metode drill dan imitasi pada paduan suara siswa kelas VII di Manado Independent School.

\section{Metode}

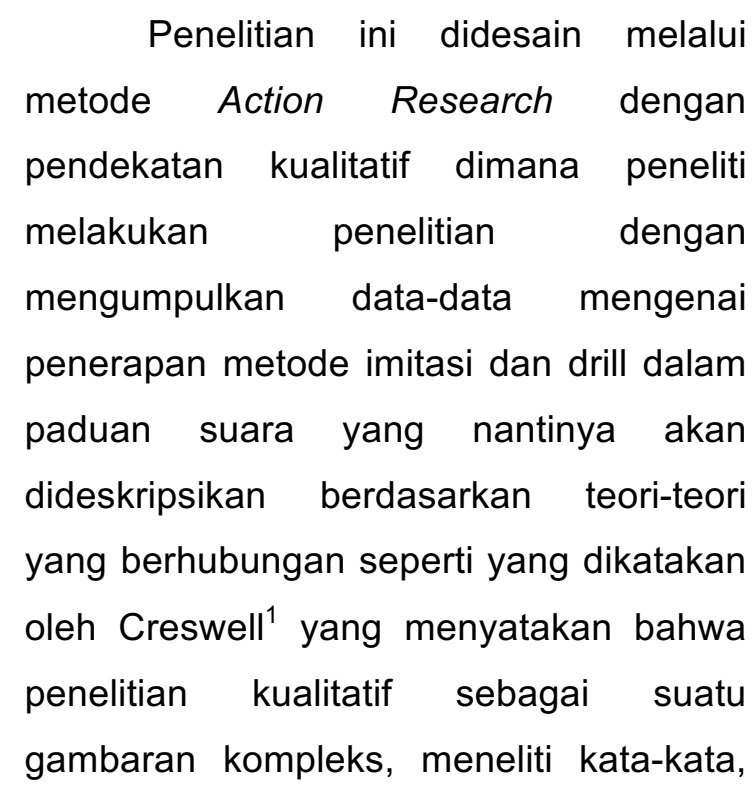

\footnotetext{
${ }^{1}$ Creswell. John W, Penelitian kualitatif dan Desain Riset, (terj; Ahmad Lazuardi), (Yogyakarta:2014)
}

laporan terinci dari pandangan responden, dan melakukan studi pada situasi yang dialami serta menggunakan landasan teori sebagai pemandu agar fokus penelitian sesuai dengan fakta dilapangan.

Adapun tahapan-tahapan yang akan dilakukan pada penelitian ini adalah :

1. Tahapan Awal

Pada tahap ini peneliti melakukan studi pendahuluan yaitu dengan mengumpulkan data-data awal yang berhubungan dengan masalah dalam penelitian termasuk kajian-kajian teori dari berbagai sumber serta menyiapkan instrument yang terdiri dari observasi, dokumentasi dan diskografi.

2. Tahapan Inti

Setelah melakukan kajian teori dan mengumpulkan data-data melalui studi pendahuluan, peneliti mengumpulkan data-data mengenai penerapan metode imitasi dan drill pada paduan suara siswa kelas VII di Manado Independent School baik melalui observasi, studi pustaka dan diskografi.

3. Tahapan Analisis Data

Pada tahap ini peneliti mengolah data yang telah dikumpulkan dari sumbersumber data yang telah ditentukan kemudian dianalisis menggunakan teknik analisis data dan hasilnya akan dituangkan dalam bentuk laporan atau pembahasan.

Penelitian dilaksanakan di Manado Independent School Kelas VII pada bulan Februari-Juni 2019. 
Sumber data penelitian adalah kelompok paduan suara siswa kelas VII di Manado Independent School dan bukubuku atau literatur yang berhubungan dengan masalah dalam karya ilmiah ini.

Teknik pengumpulan data melalui observasi, dokumentasi, studi pustaka dan analisis literatur, dan diskografi.

Data yang diperoleh peneliti sebelum penelitian hingga saat penelitian dikumpulkan dan dianalisis secara deskriptif kualitatif dimana hasil yang diperoleh mengenai penerapan metode imitasi dan drill dalam Paduan Suara siswa kelas VII di Manado Independent School dianalisis dan dideskripsikan dalam bentuk narasi yang berpedoman dari teori-teori yang berhubungan. Penelitian ini menggunakan teknik analisis data menurut Miles dan Huberman yaitu reduksi data, penyajian data, penarikan kesimpulan dan verifikasi data:

\section{Reduksi Data}

Reduksi data dalam penelitian ini dimulai sejak penetapan masalah dalam penelitian, rumusan masalah dan pengumpulan data yang dipakai. Semua data mengenai penerapan metode imitasi dan drill dalam proses latihan paduan suara siswa kelas VII di Manado Independent School yang dikumpulkan melalui observasi dan dokumentasi berupa video serta catatan hasil pengamatan tersebut dikelompokkan sesuai dengan masalah penelitian yang telah ditentukan.

\section{Penyajian Data}

Data-data penelitian yang telah di reduksi disajikan dan dianalisis sesuai dengan masalah dalam penelitian dan dideskripsikan berdasarkan fakta yang terjadi di lapangan serta dikaji sesuai dengan teori-teori yang terkait. Berbagai macam penyajian data yang dilakukan adalah uraian singkat, gambar dan video rekaman.

3. Verifikasi Data dan Kesimpulan

Verifikasi data dilakukan apabila kesimpulan yang ditarik masih bersifat sementara, dan ada perubahanperubahan sesuai dengan bukti-bukti pendukung yang ada dilapangan dan kesimpulan yang akan didapatkan diharapkan dapat menjawab fokus masalah yang telah disusun dalam penelitian.

\section{Hasil dan Pembahasan}

Ada beberapa aspek yang menjadi temuan dalam penelitian ini diantaranya:

\section{Sikap Tubuh}

Sikap tubuh yang baik saat bernyanyi yaitu sikap tubuh yang rileks atau tidak adanya ketegangan karena ketegangan dapat membuat produksi suara atau pernapasan menjadi tidak baik. Selain tidak adanya ketegangan, sikap tubuh yang baik saat bernyanyi adalah tidak bersandar ataupun tangan bertopang pada meja, tubuh lurus tidak membungkuk, serta terbebas dari beban apapun. Sikap tubuh tersebut berlaku 
untuk posisi berdiri maupun posisi duduk. Ada tiga keuntungan dari sikap tubuh yang baik saat bernyanyi yaitu memudahkan dalam bernafas, mengurangi ketegangan, dan tidak mudah lelah, hal ini berpengaruh pada kualitas vokal yang baik karena adanya support nafas yang dihasilkan dari sikap tubuh yang baik.

Sikap tubuh yang ditemui pada siswa kelas vii di manado independent school, dimana siswa masih banyak melakukan kesalahan. Seperti pada saat bernyanyi tubuh masih membungkuk yang mengakibatkan pernafasan terganggu dan berpengaru pada produksi suara. ini disebabkan karena tidak ada pemahaman yang baik dari para sisiwa pada saat bernyanyi.

\section{Intonasi}

Intonasi adalah ketepatan nada dalam bernyanyi. Jika kita bernyanyi maka setiap nada yang keluar akan membentuk melodi dari sebuah lagu. Intonasi atau ketepatan nada penting dilatih agar nada yang keluar tidak fals atau sumbang. Intonasi dibutuhkan supaya penyanyi dapat yakin bernyanyi dengan suara masing-masing supaya nada yang keluar tepat dan merupakan hasil harmoni yang terdapat pada repertoar yang dinyanyikan. Dengan kata lain dapat didefinisikan bahwa intonasi yaitu kecerdasan penyanyi membunyikan nada yang tepat pada saat bernyanyi.
Realita yang yang ditemui peneliti pada anggota paduan suara yaitu, masih ada anggota paduan suara yang intonasinya belum tepat. Hal ini terjadi karena beberapa dari mereka baru bergabung dengan tim paduan suara, juga ada yang sekedar ikut-ikuitana. Masalah tersebut membuat prores latihan menjadi terhambat karena kurangnya pengalaman mendengarkan dan membunyika nada yang tepat.

3. Artikulasi

Artikulasi adalah pengucapan katakata pada lirik lagu dengan jelas dan benar. Dalam bernyanyi, syair atau lirik memiliki peranan penting karena syair merupakan bagian penting dalam lagu dimana pesan pada lagu disampaikan melalui syair/lirik, oleh karena itu dalam melantunkan lagu seorang penyanyi harus menguasai dan melafalkan syair lagu dengan baik dan pengucapan katakatanya harus jelas dan tegas sehingga lagu tersebut menjadi lebih berkarakter, lebih hidup, dan menyentuh hati pendengarnya. Artikulasi terbagi atas 3 , yaitu artikulasi huruf vokal, artikulasi huruf konsonan, dan artikulasi huruf rangkap / diftong, berikut akan diuraikan ketiga artikulasi tersebut:

\section{a. Artikulasi Vokal (huruf hidup)}

Ada 5 vokal yang kita ketahui, yaitu a, i, u, e dan o. Kelima huruf ini yang membangun semua kata-kata dalam 
bahasa Indonesia dan juga bahasa asing lainnya.

Berikut latihan kelima vokal tersebut :

1) Vokal $A$

a. Lemaskan lidah, letakkan lidah rata diatas mulut sehingga sisi-sisi lidah menyentuh pangkal gusi, ujung lidah menyentuh akar gigi bawah.

b. Ucapkan "A" dengan membuka mulut dan menurunkan rahang bawah. Bagian belakang mulut (parynx) dan bagian depan mulut (bibir) akan terbuka.

c. Bentuk bibir atas dan bawah pada bagian depan mulut terbuka membentuk corong yang bulat.

2) Vokal "E"

a. Mulut ditarik kesamping agak lebar.

b. Ucapkan "E" dengan menurunkan rahang bawah sehingga memberi ruangan untuk membuat suara jernih dan terang.

c. Bibir jangan menjadi sempit tapi tetap seperti corong.

d. Dengan posisi seperti ini ucapkan kembali vokal "E" dengan lembut, tidak perlu berteriak.

3) Vokal I

a. Ujung lidah tetap berada dibelakang akar gigi bawah, namun bagian tengah dari lidah naik ke atas.

b. Ucapkan "l" dengan susdut bibir ditarik ke belakang. c. Gigi atas dan bawah sebaiknya kelihatan.

d. Bibir tetap dijaga membentuk corong sehingga kesan suara lebih terfokus.

e. Dengan posisi seperti ini ucapkan kembali vokal "l" dengan lembut dan rahang bawah jangan terlalu turun.

4) Vokal O dan Ô

a. Pastikanlah lidah tetap datar seperti pada huruf " $A$ ".

b. Ucapkan "O" seperti pada "toko", membentuk corong bibir diperpanjang.

c. Untuk vokal "Ô" seperti pada kata "mohon", bentuk corong bibir lebih bundar daripada huruf "O" pada kata "toko". Rahang lebih rendah dan tenggorokan dalam posisi lebih luas.

d. Dengan posisi seperti ini ucapkan kembali huruf "O" dengan memperluas rongga mulut.

5) Vokal U

a. Bibir di majukan kedepan membentuk corong yang dipersempit, Tetapi tetap bundar.

b. Ujung lidah menyentuh akar gigi sedikit membusung dibagian belakang.

c. Rahang bawah turun secukupnya.

d. Antara gigi atas dan gigi bawah diberi jarak kira-kira 1 ibu jari. 
b. Artikulasi konsonan/ Huruf mati

Konsonan merupakan bunyi bantu untuk vokal/ huruf hidup, pengucapan satu dengan yang lainnya akan berbeda berdasarkan pembentukan bunyinya.

Contoh :

1. Konsonan b, c, d, g, k, p, t disebut juga konsonan hambat oral dibunyikan dengan membentuk "hambatan" di mulut oleh alat bicara yang ada di mulut.

2. Konsonan I, m, n, r, ng, disebut juga konsonan hambat nasal, dibunyikan dengan membentuk "hambatan" di nasal. Konsonan ini disebut juga huruf mati yang bersuara.

c. Artikulasi Vokal rangkap (Diftong)

Diftong adalah bunyi dua vokal yang berurutan, keduanya berbeda antara kualitas huruf vokal awal dan akhirnya. Pengucapan setiap vokal memerlukan penyesuaian pada kerongkongan dan mulut. Dalam menyanyikan diftong, vokal pertama dinyanyikan lebih lama dari vokal keduanya, maka vokal yang mendahului diberi tekan sedikit kemudian berubah lebih rileks/luwes kebunyi vocal yang mengikutinya. Contoh : Diftong "ai" (permai, dawai, melambai), "au" (engkau, hijau, lampau), "oi" (amboina, sepoisepoi), "ia" (karunia, dunia), "ua" (semua).

Dari beberapa pendapat di atas, dapat dikatakan bahwa artikulasi adalah bunyi yang berasal dari dalam mulut dan merupakan salah satu unsur yang sangat penting dalam bernyanyi, sehingga penyanyi harus meningkatkan ucapan kata-kata agar nampak kesatuan paduan suara. tetapi kendala yang ditemui oleh peneliti dilapangan pada artikulasi yaitu, siswa sering salah dalam melafalkan lagu yang hendak dinyanyikan, doble konsonan pada beberapa pemisahan sukukata, betuk huruf vokal belum sesua dengan bentuk mulut.

\section{Pernapasan}

Menurut Paramayuda (?????), pernapasan adalah hal penting untuk diketahui, karena napas adalah penggerak utama sebuah suara. Teknik ini adalah dasar dari teknik olah vokal atau dengan kata lain seseorang tidak akan dapat bernyanyi dengan baik tanpa menguasai teknik pernapasan yang baik juga karena dalam bernyanyi membutuhkan teknik pernapasan tersendiri. Terdapat 3 jenis pernapasan dalam bernyanyi, yaitu:

\section{a. Pernapasan Dada}

Cara pernapasan ini menggunakan daya tampung dada dalam bernapas yaitu dengan cara memasukkan udara kedalam paru-paru sehingga rongga dada mengembang,namun volume udara yang didapat hanya sedikit sesuai dengan daya tampung dan kemampuan mengembang rongga dada. Cara pernapasan ini tidak dianjurkan dalam bernyanyi karena sangat pendek dan tidak mampu memberi dukungan pencapaian pada nada tinggi apalag nada panjang.

b. Pernapasan Perut 
Pernapasan perut adalah cara bernapas dengan menggunakan perut sebagai daya tampung pernapasan, sehingga mengembang dan mengempisnya paru-paru selalu diikuti dengan mengembang dan mengempisnya rongga perut. Meskipun mampu menampung udara lebih banyak disbanding dengan pernapasan dada, cara pernapasan perut belum cukup baik untuk dimanfaatkan sebagai pendukung kegiatan bernyanyi karena teknik pernapasan perut ini selain tidak cukup panjang juga sulit dikontrol dan dimanfaatkan sebagai pengantar dada yang stabil. Udara yang keluar cenderung besar dan lepas, sehingga hanya cocok untuk berteriak atau mengeluarkan suara yang keras dan pendek.

\section{c. Pernapasan Diafragma}

Diafragma merupakan sekat diantara rongga dada dan rongga perut yang dalam sistem pernapasan ini menjadi pengendali besar kecilnya udara yang keluar. Sistem pernapasan diafragma menggunakan dua rongga tubuh sekaligus yaitu rongga dada dan rongga perut, dan diatur oleh diafragma. Sehingga dengan demikian udara yang masuk cukup besar dan dapat dikendalikan.

Ada beberapa tanda yang dijadikan pegangan dan bisa dirasakan saat pernapasan diafragma, yakni :

1. Berdiri dengan tegak.

2. Raba tulang rusuk bagian bawah.
3. Letakkan dan sedikit ditekan kedua telapak tangan disisi kiri dan kanan, diantara tulang rusuk paling bawah dan perut bagian atas.

4. Inhalasi melalui hidung dengan perlahan dan lembut. Letakkan tangan kita pada pinggang bagian atas. Konsentrasi pada gerakan tulang rusuk dan sekitar perut bagian atas mengembang ke arah luar.

5. Dengan gerakan seperti di atas, kita akan merasakan telapak tangan terdorong ke luar

Dari ketiga jenis pernapasan yang disampaikan di atas, pernapasan diafragma adalah yang paling baik dan direkomendasikan untuk dilaksanakan waktu bernyanyi.

Ada tiga cara pengambilan napas, yaitu:

a. Pengambilan napas yang dalam pada awal nyanyian atau kalimat nyanyian untuk mendapatkan napas yang tahan lama dan panjang serta stabil, bisa di pakai latihan sebagai berikut:

"Paru-paru diisi dengan napas, tetapi jangan sampai terlalu penuh, napas ditahan sebentar; sambil memikirkan nada yang akan dinyanyikan; kemudian napas dikeluarkan dengan menyanyikan 'mo' selama 5 detik. Sesudah itu ambillah napas baru, di tahan lagi sebentar dan dikeluarkan dengan bernyanyi 'me' selama 10 detik. Lalu ambillah napas lagi, tahanlah napas itu sebentar dan keluarkan selama 20 detik sambil menyanyikan 'no'." 
b. Mencuri napas di tengah nyanyian bila tidak ada saat mengambil napas.

c. Pengambilan napas secara bergantian. Pengambilan napas dengan teknik ini khusus dipakai dalam paduan suara. Bila ada suatu nada yang ditahan panjang dan tidak boleh di putus, maka pengambilan napas dilakukan dengan tidak serempak oleh seluruh kelompok suara, namun berganti-gantian oleh masing-masing penyanyi. Dengan demikian timbul kesan seakan-akan nada itu berhasil ditahan panjang, tanpa mengambil napas.

Penguasaan sistem pernapasan diafragma mutlak diperlukan dalam bernyanyi karena dalam bernyanyi diperlukan napas-napas panjang untuk menggapai nada tinggi dan rangkaian nada yang panjang dalam lagu. Tapi kenyataanya masih banyak anggota paduan suara yang masih salah dalam hal pernafasan. Beberapa anggota paduan suara masih menggunakan nafas dada, kegiatan tersebut berpengaru pada nada panjang karena udara yang dihasilkan hanya sedikit, membuat penyanyi cepat lelah dan produksi suara kurang baik.

\section{Ekspresi}

Ekspresi adalah cara yang dilakukan penyanyi untuk membawakan lagu dengan baik dari suatu ciptaan sesuai dengan jiwa lagu tersebut. Misalnya sedih, gembira, semangat dan lain-lain. Ekspresi adalah sesuatu yang bersifat menyatakan perasaan yang mencakup semua nuansa dari dinamik, tempo atau kecepatan musik dan warna suara yang disampaikan pada pendengarnya. Secara umum ekspresi berperan pada suasana lagu tersebut, kemudian membuat rangsangan imajinatif kepada pendengar untuk ikut mengalami keadaan atau peristiwa yang diinginkan oleh penyanyi dari lagu yang dinyanyikan.

Paduan suara kelas vii berjumlah 24 orang, tetapi banyak yang masih malu ketika diminta bernyanyi. Hal ini membuat penyanyi tidak bisa berkonsentrasi dan berimajinatif untuk membuat rangsangan kepada pendenga agar pendenga mengalami keaadan yang diinginkan oleh penyanyi. Beberapa anggota paduan suara masih banyak yang kurang fokus dengan pembelajaran karena hanya ikutikutan berlatih pada saat pembelajaran berlangsung.

Beberapa aspek tersebut diatas merupakan topik kajian yang dilakukan dalam implementasi dari metode imitasi dan drill.

\section{Kesimpulan}

Berdasarkan temuan-temuan dalam penelitian dapat disimpulkan bahwa penerapan metode imitasi dan drill dalam pembelajaran paduan suara siswa kelas VII di Manado Independent School menghasilkan penggunaan teknik vokal yang baik. Para siswa mampu menerapkan teknik bernafas dengan 
benar, intonasi yang baik, mengucapkan artikulasi dengan jelas, sikap tubuh yang benar serta mampu mengekspresikan isi lagu dengan baik. Hal ini dapat dilihat dari perkembangan belajar siswa sebelum menggunakan metode dan sesudah menggunakan metode.

Dapat diuraikan hasil ketuntasan belajar siswa seperti berikut ini: Angka sikap tubuh pada waktu pretes yaitu $25 \%$, setelah menggunakan metode imitasi angkanya beruba menjadi $45.83 \%$, sedangkan intonasi $20.83 \%$ menjadi $45.83 \%$, pernafasan $20.83 \%$ menjadi $50 \%$, artikulasi $45.83 \%$ menjadi $68.95 \%$, dan ekspresi $16.66 \%$ menjadi $70.83 \%$. sedangkan nilai rata-rata dari siswa sebelum dan sesuda menggunakan metode imitasi dan drill dapat diuraykan sebagai berikut: nilai sikap tubuh pada saat pretes yaitu $61.04 \%$ menjadi $64.16 \%$, intonasi $59.58 \%$ menjadi $65.41 \%$, pernafasan $58.95 \%$ menjadi $63.95 \%$, artikulasi $61.66 \%$ menjadi $68.33 \%$ dan ekspresi $59.62 \%$ menjadi $68.33 \%$. hal ini membuktikan bahwa ada perkembangan yang signifikan pada saat menggunakan metode imitasi tersebut.

Kendala yang sering muncul dalam pembelajaran yaitu pernapasan dan intonasi. Penanggulangan yang dilakukan adalah dengan melakukan pengulangan disetiap pertemuan yang dibantu oleh pelatih dengan mencontohkan pernapasan juga intonasi yang terdapat pada lagu dan diikuti oleh anggota paduan suara. secara gari besar penanggulangan dari setiap kendala yaitu dengan melakukan pengulangan yang disertai dengan penambahan materi sedikit demi sedikit.

Sesuai dengan rumusan masalah yang kedua, dengan adanya penerapan metode imitasi dan drill dalam proses latihan paduan suara siswa kelas VII dapat mengikuti setiam materi yang diberikan oleh pelatih. Dalam hal ini kegiatan pembelajaran penulis selaku peneliti menggunakan metode imitasi untuk mempermuda anak-anak dalam pembelajara vokal dan penguasaan lagu, sehingga anak-anak dapat menirukan apa yang di contohan oleh pelatih, serta dapat menguasai teknik vokal dan lagu yang diajarkan dengan menggunakan metode drill atau secara berulang ulang.

Hal tersebut diatas membuktikan bahwa metode imitasi dan drill merupakan metode yang tepat untuk diterapkan dalam pembelajaran paduan suara pada siswa kelas VII di Manado Independent School.

\section{Daftar Pustaka}

Aley, Ririe (2010), Intisari Olah Vokal, Yogyakarta : PT. Gramedia

Banoe, Pono (2003), Kamus Musik. Yogyakarta : Kanisius.

Chyntia A. Lubis, (2016) Skripsi : Proses Pembelajaran Teknik Vokal Pada Paduan Suara Bina Vokalia Di SD Pangudi Luhur Yogyakarta ,2016 
http://digilib.isi.ac.id/1622/ (Diakses 5 Maret 2019)

David, Julia. (2012), LaTour, Stephen, Vocal Technique, Amerika : Waveland Press

M, Rudy, (2008) Panduan Olah Vokal, Yogyakarta: Media Pressindo

Paramayuda, Yudha (2010). Buku Pintar Olah Vokal. Yohyakarta : Buku biru.

Pusat Musik Liturgi, (2016). Menjadi Dirigen II, Yogyakarta: Pusat Musik Liturgi

Roestiyah\&Suharto, Yumarti, (1995). Strategi Belajar Mengajar. Bandung : Bina Aksara.

Sudjana. (2005). Metoda Statistika, Bandung : Tarsito Bandung

Soeharto, AH, (1982). Membina Paduan Suara dan Grup Vocal, Jakarta : PT. Gramedia.

Umbulele, Aryanti A., (2013) "Upaya Meningkatkan Teknik Vokal Pada Paduan Suara Inovatif Dengan Menggunakan Metode Imitasi Dan Drill" 2013, http://eprints.uny.ac.id/19607/1/Arya nti\%20Anita\%20Umbu\%20Lele\%20 09208244043.pdf (Diakses 5 Maret 2019) 